\section{Nationalism and Use of Land}

IN an article on "Nationalism and Land Utilisation in Britain" in the Geographical Review of January, Dr. Dudley Stamp directs attention to some of the results of a nationalistic policy in agriculture. Agricultural returns for 1935 and 1936 show an increase in arable acreage and in the total area of improved land, due to protective tariffs, marketing subsidy and, above all, the wheat quota. These schemes lead to excessive specialization in the commodities thus favoured, and they may, by bringing hill slopes under the plough, do more harm than good by the promotion of soil erosion. Again, the general application of, say the wheat quota, throughout the country overlooks the fact that though very little of the country is definitely outside the limits of wheat cultivation, a great part of it is not favourable, and would be harmed by constant soil disturbance. Another important consideration that is overlooked is the very small area of really first-class soils suitable for intensive arable farming such as market gardening, and yet near London and other great towns, where these products are most required, building is allowed to spread regardless of the value of the soil. Furthermore, in the 'reconditioning' of the land, or regrading to a fuller use, it is necessary to supplement the economic standard of judgment, cost per unit, by a standard of nutritional value, and pay more attention to meat and dairy products, poultry farming, and fruit and vegetable production.

\section{Experiments in Resuscitation}

A Report by the Soviet Union Year Book Press Service relates that ten years ago Dr. Sergei Briukhonenko carried out the following experiment. $\mathrm{He}$ removed the head of a dog and attached to it an spparatus which he called the autojector for artificial circulation of the blood, with the result that the severed head was kept alive for six months, reacting to all stimuli. Some years later, Dr. Briukhonenko succeeded in resuscitating a whole animal. A dog had its thorax opened and the action of the heart stopped. Death set in, but the animal was revived by the autojector. In 1936 the Institute of Experimental Physiology and Therapy was created to assist Dr. Briukhonenko in his researches. The result has been that not only has resuscitation been effected so long as half an hour after death, but also life has been maintained so that dogs which were put to death in various ways in August and September 1936 and then resuscitated are still alive and in excellent condition.

\section{Lambeth Degrees}

AN interesting note on these degrees, by Dr. Cecil Wall, appears in the "Brompton Hospital Reports", vol. 5, 1936. The power to grant such doctorates in any faculty was given to the Archbishop of Canterbury in 1534 through the Act of Supremacy and Succession. A number of degrees in medicine and science, apart from other faculties, have thus been conferred. The Lambeth doctorates were usually conferred for eminent service on those who were unable to conform with the university regulations for internal degrees. Among the men of science who received such degrees on the dates mentioned were Robert Hooke, physicist and secretary of the Royal Society (1691), John Woodward, geologist (1695), and Peter Dent, botanist (1678).

\section{Books on Industrial Management}

The Management Library (23, Bloomsbury Square, W.C.1) has issued a list of forty-seven recommended books on industrial organization and management arranged under such headings as scientific management, finance and accounting, production management, distribution, advertising, commercial and industrial training. The Library contains some further three thousand volumes, and detailed lists, constituting a catalogue, are available free on (1) general management; (2) production; (3) accounting and company secretary ; (4) distribution, including retailing; (5) rationalization; (6) psychology; (7) economics; ( (8) industrial biographies. Short critical reviews are published to keep members up to date as well as an annual cumulative subject-indexed guide to book selection.

\section{Astronomical Society of the Pacific}

Ar the annual meeting of the Astronomical Society of the Pacific held in San Francisco on January 30, it was announced that the Catherine Wolfe Bruce Gold Medal for 1937 has been awarded to Prof. Ejnar Hartzsprung, director of the University Observatory, Leyden, Holland. In announcing the award, the president of the Society for 1936, Prof. A. O. Leuschner, gave an account of Dr. Hertzsprung's outstanding contributions to astronomy. Announcement has been made by the Director, Dr. W. H. Wright, of provision for an annual appointment to be known as the Alexander F. Morrison Memorial research associateship in the Lick Observatory. Appointments to the research associateship will be made by the regents of the University of California. "The appointee shall be an astronomer, or an authority on some other subject intimately related to astronomy, of wide and admirable repute by virtue of contributions of great value which he has made to the science of astronomy. The holder of the Research Associateship will reside at Mount Hamilton as a guest member of the staff for a certain portion of a year as would be agreed upon." Prof. Hertzsprung has accepted an invitation to be the first visitor under the new foundation.

\section{A New Comet}

A COMET of about the seventh magnitude was discovered during the evening of February 27 at the position R.A. $0^{\mathrm{h}} 35 \cdot 3^{\mathrm{m}}$ : Dec. $19^{\circ} 22^{\prime} \mathrm{N}$. (at $18^{\mathrm{h}} 25 \cdot 1^{\mathrm{m}}$ U.T.). It was first reported to the Central Bureau at Copenhagen by Prof. A. Wilk of the Cracow Observatory, Poland, but apparently the comet was discovered almost simultaneously by observers elsewhere. From observations made since February 27 at Warsaw, Meudon, Copenhagen, in England and elsewhere, two preliminary orbits have been com- 
puted, but the one given by Whipple and Cunningham of the Harvard College Observatory appears to fit the observations the better. The elements of this orbit give the date of perihelion as $1937 \mathrm{Feb} .21 \cdot 73$ U.T. and perihelion distance as $0.620\left(\omega=32^{\circ} 9^{\prime}\right.$ : $\left.\Omega=57^{\circ} 3^{\prime}: i=25^{\circ} 57^{\prime}\right)$. Thus during the present week the comet is receding from the sun, but its distance from the earth is decreasing. In consequence its brightness has remained nearly stationary, though possibly it may reach a maximum about March I3 or 14; although the comet is not a naked-eye object, it should be within the range of binoculars. On February 27, the comet was near the borders of the constellations of Pisces and Andromeda; since then it has been traversing the latter constellation, being near the bright star $\beta$ Andromedæ in the evening of March 10; the comet's path, continued through Perseus, will have entered Cassiopeia on March 24. In Great Britain the comet has been photographed two or three times by Mr. G. F. Kellaway of Yeovil, Somerset; a short tail to the nucleus is shown on the photographs. Dr. A. C. D. Crommelin thinks that it is worth while to examine the possibility of identity of the present comet with that of the comets of 1532 and 1661 .

\section{Announcements}

HoNORARY membership of the Royal Asiatic Society has been conferred upon Prof. Jules Bloch, of the University of Paris, Prof. Carl Brockelmann, of the University of Breslau, and Prof. J. Ph. Vogel, of the University of Leyden, in recognition of their eminent services to Oriental research.

THE Royal Society of Edinburgh has awarded the Gunning Victoria Jubilee Prize for the period 1932-36 to Prof. C. G. Darwin, master of Christ's College, Cambridge, formerly Tait professor of natural philosophy in the University of Edinburgh, for his distinguished contributions in mathematical physics ; and the Makdougall-Brisbane Prize for the period 1934-36 to Dr. E. M. Anderson, formerly of H.M. Geological Survey (Scotland), for his paper "The Dynamics of the Formation of Cone-sheets, Ringdykes, and Caldron-subsidences", published in the Society's Proceedings within the period of the award.

According to Science and Culture, at the annual meeting of the National Institute of Sciences of India held at Hyderabad on January 5, the following officers were elected for the current year : President, Prof. M. N. Saha; Vice-Presidents, Prof. S. S. Bhatnagar and Lieut-Colonel R. N. Chopra ; Foreign Secretary, Prof. B. Sahni ; Secretaries, Prof. S. P. Agharkar and Dr. A. M. Heron; Treasurer, Dr. S. L. Hora.

AT the annual general meeting of the Geological Society of London held on February 19, the following officers were elected for 1937-38: President, Prof. O. T. Jones; Vice-presidents, Prof. W. T. Gordon, Mr. J. F. N. Green, Prof. W. J. Pugh, and Prof. H. H. Swinnerton; Secretaries, Dr. L. Hawkes and Prof. W. B. R. King; Foreign Secretary, Sir Arthur Smith Woodward; Treasurer, Mr. F. N. Asheroft.
Ax the annual general meeting of the Society of Public Analysts and Other Analytical Chemists held on March 5 the following officers were elected for 1937 : President, G. Roche Lynch; Vice-Presidents, A. L. Bacharach, H. E. Cox, B. S. Evans, A. R. Tankard, J. F. Tocher; Hon. Treasurer, E. B. Hughes; Hon. Secretary, Lewis Eynon.

THE International Commission of Zoological Nomenclature has elected Mr. Francis Fleming to be secretary in succession to Dr. C. W. Stiles, who has resigned on account of ill-health. The Secretary's address is : British Museum (Natural History), Cromwell Road, London, S.W.7.

BeGINNING on April I, the Victoria and Albert Museum, including the India Museum, and also the Science Museum, South Kensington, are to remain open on Thursdays, Fridays and Saturdays until 8 p.m. At present the Museums close at 6 p.m. The Museums will remain open until 8 o'clock on the Monday bank holidays at Easter, Whitsun and August.

ThE University of Lille has accepted the 15,000 francs awarded to Dr. Cloudesley Brereton for his book on France by the Commission du Tourisme, for a prize to be awarded in alternate years for the best essay on the works of M. Izoulet, of the College of France, and on Mr. Branford's work, "Eros and Psyche" (University of London Press).

Jean Chazy has been elected a member of the Section of Astronomy of the Paris Academy of Sciences in succession to the late M. Hamy.

Prof. Heinkich GLobl, of Wetzlau, has been awarded the Goethe Medal for Art and Science.

Prof. P. RIVET, professor of anthropology in the Museum of Natural History, Paris, has been created a Commander of the Legion of Honour.

Prof. L. van Itallie, of Leyden, recently delivered an address before the French Society of Clinical Biology, after which he was awarded the Pasteur Medal.

Prof. Karl Beurlen, professor of geology and palæontology at Kiel, Prof. Albert Dietrich, professor of pathology at Tübingen, and Prof. Hans Seger, director of the Silesian Museum for Art and Antiquities, Breslau, have been elected members of the Imperial Leopold Caroline German Academy at Halle.

THE Rockefeller Foundation has made a grant of 10,000 dollars for the investigation of filterable viruses under the direction of Dr. George P. Berry, professor of bacteriology and associate professor of medicine at the University of Rochester (U.S.A.), and one of 6,400 dollars for the study of the biological effects of heat by Dr. Stafford L. Warren, associate professor of medicine and radiology. 